\title{
Review of the Survey's activities in 1988
}

\author{
Martin Ghisler \\ Director
}

During 1988 GGU started two major field projects in Greenland, one in North-East Greenland, and another in West Greenland in the Disko Bugt area. In addition petroleum geological investigations in Jameson Land and glacio-hydrological studies in West Greenland continued. A total of 84 participants were engaged in the field work.

The scientific and technical staff at GGU in Copenhagen continued research on material collected in Greenland; total staff including administrative personnel numbers at present 108. A 10 per cent reduction of the staff is forecast over the next four years, combined with an additional reduction of the budget by 14 per cent. Accordingly, decreasing activity in both field work in Greenland and laboratory work in Copenhagen is expected. This development, rather similar to the trend in other western European geological surveys, will lead to a relatively greater engagement in applied geological projects and to less basic geological research.

The Act on Mineral Resources in Greenland was revised in 1988 by agreement between the Danish Parliament and the Greenland Home Rule Authority. In accordance with this, all revenues from mineral exploitation in Greenland up to 500 million kroner per year will be distributed with $50 \%$ to the Danish State and $50 \%$ to the Greenland Home Rule Authority, independent of the annual capital transfers from Denmark to Greenland. In addition the Home Rule Authority's access to, insight into, and influence on the Danish administration of Greenland's mineral resources (including GGU) are increased in various respects. The agreement is valid until at least 1995 .

\section{East Greenland}

In North-East Greenland the investigation began of the least known area between latitudes $75^{\circ}$ and $81^{\circ} \mathrm{N}$. The area between $75^{\circ}$ and $78^{\circ} \mathrm{N}$ will be surveyed in the years 1988-90, whereas the area between $78^{\circ}$ and $81^{\circ} \mathrm{N}$ is planned to be investigated in a second phase. The purpose of the programme is a systematic geological investigation on a regional scale leading to an understanding of the Caledonian and pre-Caledonian geology and to production of two map sheets in the 1:500 000 geological series. In addition the programme will include a preliminary evaluation of the mineral potential of the area and, combined with existing aeromagnetic and planned marine-seismic surveys, will contribute to a better understanding of the geology and hydrocarbon potential of the off-shore area.

In 1988, 23 participants from GGU and 6 from the Geodetic Institute were supported by helicopter from a base camp north of Daneborg, $300 \mathrm{~km}$ north of Mesters Vig. The main activities were concentrated on the crystalline rocks of the Caledonides between $75^{\circ}$ and $76^{\circ} \mathrm{N}$ and were accompanied by more detailed studies south of $75^{\circ} \mathrm{N}$ on the sedimentary features of the late Precambrian Eleonore Bay Group, the palaeontology of Lower Palaeozoic strata, and the sedimentological and structural development of the Devonian basin.

In the Jameson Land area, a group of 13 GGU staff members participated in various hydrocarbon research activities. Two teams, one financially supported by British Petroleum, made detailed sedimentological studies on selected profiles of Mesozoic sequences. Another group performed a shallow drill programme on selected reservoir rocks in collaboration with ARCO/AGIP.

In the Kangerdlugssuaq area the alkaline Gardiner intrusion was briefly visited for additional sampling.

Four scientists from GGU joined the German research vessel 'Polarstern' on two marine-seismic cruises to Scoresby Sund and the North-East Greenland shelf as far north as $80^{\circ} \mathrm{N}$.

\section{West Greenland}

GGU's helicopter- and boat-supported field activities in West Greenland in 1988 were concentrated in the Disko Bugt area, and it is planned to continue these activities in 1989 and also in 1991-92. Operations in 1988 were based on an abandoned settlement Atâ $75 \mathrm{~km}$ north of Jakobshavn, and there were 30 participants in the group. The main emphasis was given to a study of the mineral potential of the area, especially the Precambrian volcanics and their sulphide and gold mineralizations. One group made structural and sedimentological studies of the sediments on Nûgssuaq as a contribution to the re-evaluation of the petroleum potential of 


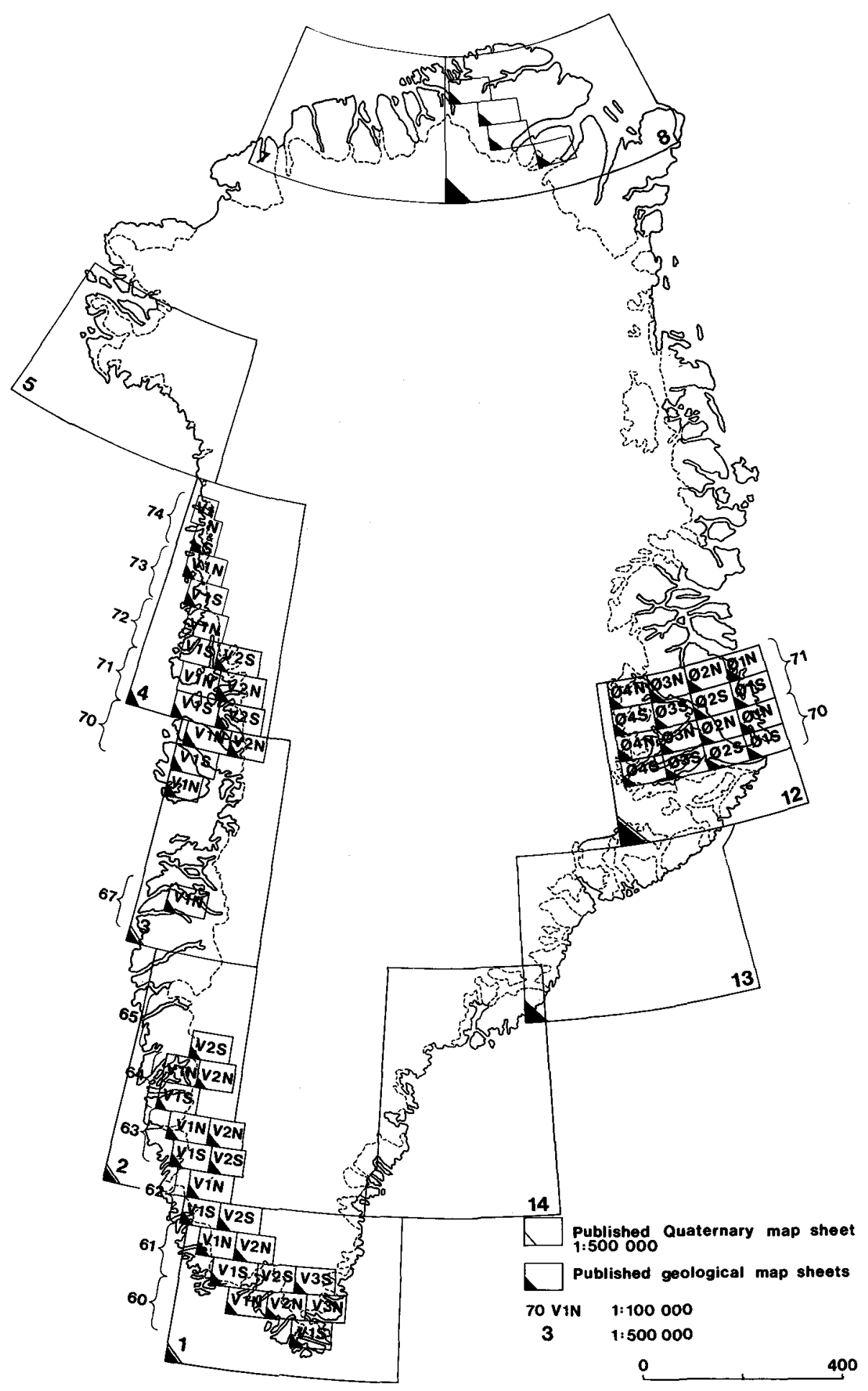

Fig. 2. Map sheets published and in preparation by the Survey (see inside back cover). 
the West Greenland Cretaceous-Tertiary sedimentary basin. The programme was carried out in close cooperation with staff and students from the University of Copenhagen, financially supported by the Danish Natural Science Research Council. Special attention from this group was given to the Tertiary basalts of eastern Disko and southern Nûgssuaq and the underlying sediments, and to the Precambrian granitoid rocks around Atâ and the supracrustal belt which partially surrounds the Atâ granite.

In close logistic collaboration with the Atâ group, an international team of 13 scientists from Switzerland, U.S.A., The Netherlands, Germany and GGU undertook glaciological investigations at Pâkitsoq north of Jakobshavn. The GGU work was mainly devoted to glacio-hydrological studies related to hydropower developments, including both hot-water drilling and tracer experiments. In addition glaciological and hydrological data were collected from GGU's two field stations near Nuuk/Godthåb and Søndre Strømfjord as part of the on-going mass balance studies of the West Greenland ice margin.

The laboratory investigations of the niobium-tantalum deposits around Motzfeldt $S \emptyset$ in South Greenland, financed by a special grant from the Mineral Resources Administration, were completed.

\section{General}

GGU assisted the Mineral Resources Administration (MRA) with geological and environmental inspection of
Greenex's exploitation of the Black Angel lead-zinc deposit at Maarmorilik. The geochemical part of the environmental control has hitherto been carried out in a collaboration between GGU and the Greenland Environmental Research Institute (GM). In 1988 it was decided to transfer the GGU laboratory and staff involved to GM in order to gather the environmental expertise connected with mineral activities in Greenland together in one institution.

GGU also assisted the MRA with the evaluation of geophysical and geological data from Jameson Land collected by ARCO. GGU inspected the mineral exploration activities of concessionaires on Nûgssuaq, on Nunarssuit south of Ivigtut, at Agpat and Kangerdluarssuk south of Narsaq, at Amitsoq and Sarqa north of Nanortalik, all in West Greenland. In East Greenland the mineral exploration activities at the Skaergaard intrusion at Kangerdlugssuaq were inspected.

During the year the 1:500 000 geological map sheet 'Kangerdlugssuaq' and the 1:500 000 Quaternary map sheet 'Scoresby Sund' were printed. The 1:100 000 geological map 'Ivisartoq' (64 V.2 N) near Nuuk/Godthåb and a special map at 1:20 000 of the southern part of the Ilímaussaq Intrusion at Narsaq were also printed, as well as four aeromagnetic maps at 1:1000 000. Five Reports, one map sheet description and one Open File Report were published. In the popular series Geologi $i$ Grønland one contribution appeared in Danish on the glaciers in South Greenland. As a result of GGU activities a number of contributions were published in international scientific journals in 1988, which together with GGU's own publications are listed below.

\section{Publications 1988}

\section{Maps in series}

Chadwick, B. \& Coe, K. 1988: Geologisk kort over Grønland, 1:100 000, Ivisârtoq 64 V.2 Nord.

Myers, J. S., Dawes, P. R. \& Nielsen, T. F. D. 1988: Geologisk kort over Grønland, 1:500 000. Kangerdlugssuaq. Sheet 13.

Funder, S. 1988: Quaternary map of Greenland, 1:500 000, Sheet 12 , Scoresby Sund.

\section{Maps outside series}

Andersen, S., Bohse, H. \& Steenfelt, A. 1988: The southern part of the Ilímaussaq complex, South Greenland, 1:20 000 .

\section{Map sheet description}

Henriksen, N. \& Higgins, A. K. 1988: Geological map of Greenland 1:100 000. Descriptive text. Rødefjord 70 $\varnothing .3$
Nord, Kap Leslie $70 \varnothing .2$ Nord. The pre-Caledonian, Caledonian and post-Caledonian geology of Milne Land and adjacent areas, Scoresby Sund region. 34 pp., 15 figs, 4 tables, 2 maps."

\section{Aeromagnetic anomaly maps 1:1 000000}

Sheet $260^{\circ}-64^{\circ} 30^{\prime} \mathrm{N}, 32^{\circ}-44^{\circ} \mathrm{W}$. East Greenland. 1988.

Sheet $363^{\circ} 30^{\prime}-68^{\circ} 30^{\prime} \mathrm{N}, 23^{\circ}-41^{\circ} \mathrm{W}$. East Greenland. 1988.

Sheet $4 \quad 69^{\circ}-74^{\circ} \mathrm{N}, 19^{\circ}-27^{\circ} \mathrm{W}$. East Greenland. 1988.

Sheet $569^{\circ} 30^{\prime}-78^{\circ} \mathrm{N}, 12^{\circ}-24^{\circ} \mathrm{W}$. East Greenland. 1988 . 


\section{Rapporter (Reports)}

Nr. 137. Peel, J. S. (ed.) 1988: Cambrian-Jurassic fossils, trace fossils and stratigraphy from Greenland. 159 pp., 70 figs, 1 table, 5 plates.

Nr. 138. Thomsen, H. H., Thorning, L. \& Braithwaite, R. J. 1988: Glacier-hydrological conditions on the Inland Ice north-east of Jakobshavn/Ilulissat, West Greenland. 1 map with text.

Nr. 139. Dawes, P. R. 1988: Etah meta-igneous complex and the Wulff structure: Proterozoic magmatism and deformation in Inglefield Land, North-West Greenland. 24 pp., 12 figs, 1 table.

Nr. 140. Grønlands Geologiske Undersøgelse 1988: Report of activities, 1987. 124 pp., 79 figs, 17 tables.

Nr. 141. Schiøtte, L. 1988: Field occurrence and petrology of deformed metabasite bodies in the Rinkian mobile belt, Umanak district, West Greenland. 36 pp., 34 figs, 9 tables.

\section{Open-file series}

88/1. Thomassen, B. 1988: The Motzfeldt 87 project. Final report. 81 pp., 5 figs, 9 tables, 42 appendices with 8 overlays.

\section{Recipientunders $\emptyset$ gelse}

Miljøundersøgelse ved Maarmorilik 1972-1987. Nov. 1988.

\section{Popular scientific series}

Weidick, A. 1988: Gletschere i Sydgønland. Historie, Natur, Omgivelser. Geologi $i$ Grønland 2, 80 pp., 52 figs, 2 tablès.

\section{Other scientific articles}

Appel, P. W. U. 1988: Tourmaline in Precambrian supracrustal rocks from Aasiaat, central West Greenland. Rapp. Grønlands geol. Unders., Nr. 140, 44-46, 1 table.

Appel, P. W. U. 1988: Scheelite in Malene supracrustals of the Ivisârtoq area, southern West Greenland. Rapp. Grønlands geol. Unders., Nr. 140, 57-58.

Appel, P. W. U. 1988: On an Sn-W-bearing iron-formation in the Archaean Malene supracrustals, West Greenland. Precambrian Res., vol. 39, 131-137, 1 fig., 1 table (Misc. Pap. Grønlands geol. Unders., No. 408).

Appel, P. W. U. 1988: Gold exploration in West Greenland. Newsletter int. Liason Group Gold Mineralization, No. 6, 3-4, 1 fig.

Appel, P. W. U. 1988: Tungsten mineralization in the Archean of West Greenland. Krystalinikum, vol. 19, 9-20, 2 figs, 1 table.

Appel, P. W. U. 1988: Stratiform tourmalinites in the Archaean tungsten province of West Greenland. Miner. Petrol., vol. 39, 79-91, 5 figs, 1 table (Misc. Pap. Grønlands geol. Unders., No. 415).

Appel, P. W. U. \& Knudsen, C. 1988: Stream sediment sam- pling in the Atâ area, central West Greenland. Rapp. Grønlands geol. Unders., Nr. 140, 24-26, 1 fig., 1 table.

Appel, P. W. U. \& Mahabaleswar, B. 1988: Secular trends in rare earth element patterns of Precambrian iron-formations from India and Greenland. J. geol. Soc. India, vol. 32, 214-226, 3 figs, 4 tables.

Bendix-Almgreen, S. E. \& Peel, J. S. 1988: Hadimopanella from the Lower Cambrian of North Greenland: structure and affinities. Bull. geol. Soc. Denmark, vol. 37, 83-103, 12 figs.

Bendix-Almgreen, S. E., Clack, J. A. \& Olsen, H. 1988: Upper Devonian and Upper Permian vertebrates collected in 1987 around Kejser Franz Joseph Fjord, central East Greenland. Rapp. Grønlands geol. Unders., Nr. 140, 95102,5 figs.

Bengaard, H.-J. 1988: Basic rocks of the inner Fiskefjord area, southern West Greenland. Rapp. Grønlands geol. Unders., Nr. 140, 55-56, 2 figs.

Bergström, J. \& Peel, J. S. 1988: Lower Cambrian trace fossils from northern Greenland. Rapp. Gronlands geol. Unders., Nr. 137, 43-53, 8 figs.

Blaker, M. R. 1988: A new genus of nevadiid trilobite from the Buen Formation (Early Cambrian) of Peary Land, central North Greenland. Rapp. Grønlands geol. Unders., Nr. 137, 33-41, 6 figs, 1 table.

Braithwaite, R. J. 1988: New approaches to studying effects of glacier ablation on runoff in Greenland. In Thomsen, H. H., Søgaard, H. \& Braithwaite, R. J. (ed.) Applied hydrology in the development of northern basins. Proc. 7 th Northern Research Basins Symposium/Workshop, 1988, Ilulissat, 71-76. København: Selskabet for Arktisk Teknologi.

Braithwaite, R. J. 1988: Estimating glacier melt from bulkexchange coefficients. J. Glaciol., vol. 34, 365-366.

Braithwaite, R. J. \& Olesen, O. B. 1988: Effect of glaciers on annual run-off, Johan Dahl Land, South Greenland. J. Glaciol., vol. 34, 200-207, 6 figs, 3 tables (Misc. Pap. Grønlands geol. Unders., No. 406).

Braitwaite, R. J. \& Olesen, O. B. 1988: Winter accumulation reduces summer ablation on Nordbogletscher, South Greenland. Z. Gletscherk. Glazialgeol., vol.24, 21-30, 5 figs, 2 tables (misc. Pap. Grønlands geol. Unders., No. 416).

Chalmers, J. A. 1988: Application of seismo-stratigraphic interpretation techniques to offshore West Greenland. Rapp. Grønlands geol. Unders., Nr. 140, 64-66, 2 figs.

Dan, G. 1988: Sedimentological studies of the fluviatile-shallow marine Upper Triassic to Lower Jurassic succession in Jameson Land, East Greenland. Rapp. Grønlands geol. Unders., Nr. 140, 76-79, 1 fig.

Dawes, P. R. 1988: Etah meta-igneous complex and the Wulff structure: Proterozoic magmatism and deformation in Inglefield Land, North-West Greenland. Rapp. Gronlands geol. Unders., Nr. 139, 24 pp., 12 figs, 1 table.

Dawes, P. R., Larsen, O. \& Kalsbeek, F. 1988: Archean and Proterozoic crust in North-West Greenland: evidence from Rb-Sr whole-rock age determinations. Can. J. Earth Sci., vol. 25, 1365-1373, 9 figs, 3 tables. (Misc. Pap. Grønlands geol. Unders., No. 417)

Dueholm, K. S. \& Pedersen, A. K. 1988: Geological pho- 
togrammetry using oblique aerial photographs. Rapp. Grønlands geol. Unders., Nr. 140, 33-38, 3 figs.

Fletcher, T. P., Higgins, A. K. \& Peel, J. S. 1988: A BaltoScandian Middle Cambrian fauna from Peary Land, North Greenland. Rapp. Grønlands geol. Unders., Nr. 137, 18 only.

Friend, C. R. L. \& Nutman, A. P. 1988: Evolution and emplacement of Archaean terranes in the Kapisigdlit area, southern West Greenland. Rapp. Grønlands geol. Unders., Nr. 140, 59-64, 2 figs, 1 table.

Funder, S. \& Abrahamsen, N. 1988: Palynology in a polar desert, eastern North Greenland. Boreas, vol. 17, 195-207, 8 figs, 3 tables. (Misc. Pap. Grønlands geol. Unders., No. 407).

Garde, A. A. \& Marker, M. 1988: Corundum crystals with blue-red colour zoning near Kangerdluarssuk, Sukkertoppen district, West Greenland. Rapp. Gronlands geol. Unders., Nr. 140, 46-49, 1 fig.

Ghisler, M. 1988: Review of the Survey's activities in 1987. Rapp. Gronlands geol. Unders., Nr. 140, 5-7, 2 figs.

Gill, R. C. O., Nielsen, T. F. D., Brooks, C. K. \& Ingram, G. A. 1988: Tertiary volcanism in the Kangerdlugssuaq region, E Greenland: trace-element geochemistry of the Lower Basalts and the tholeiitic dyke swarm. In Morton, A. C. \& Parson, L. M. (ed.) Early Tertiary volcanism and the opening of the NE Atlantic. Spec. Publ. geol. Soc. Lond., No. 39, 161-179, 10 figs, 2 tables \& 1 table in appendix (Misc. Pap. Grønlands geol. Unders., No. 412).

Hansen, Kirsten 1988: Preliminary report of fission track studies in the Jameson Land basin, East Greenland. Rapp. Grønlands geol. Unders., Nr. 140, 85-89, 2 figs, 3 tables.

Higgins, A. K. 1988: The Krummedal supracrustal sequence in East Greenland. In Winchester, J. A. (ed.) Later Proterozoic stratigraphy of the northern Atlantic regions, 86-96, 16 figs. Glasgow: Blackie \& Son, New York: Chapman \& Hall.

Higgins, A. K. 1988: Glacier velocities from aerial photographs in North and North-East Greenland. Rapp. Grønlands geol. Unders., Nr. 140, 102-105, 1 fig.

Kalsbeek, F., Taylor, P. N. \& Pidgeon, R. T. 1988: Unreworked Archaean basement and Proterozoic supracrustal rocks from northeastern Disko Bugt, West Greenland: implications for the nature of Proterozoic mobile belts in Greenland. Can. J. Earth Sci., vol. 25, 773-782, 8 figs, 5 tables (Misc. Pap. Grønlands geol. Unders., No. 413).

Knudsen, C., Appel, P. W. U., Hageskov, B. \& Skjernaa, L. 1988: Geological reconnaissance in the Precambrian basement of the Atâ area, central West Greenland. Rapp. Grønlands geol. Unders., Nr. 140, 9-17, 5 figs, 2 tables.

Konnerup-Madsen, J., Kreulen, R. \& Rose-Hansen, J. 1988: Stable isotope characteristics of hydrogen gases in the alkaline Ilímaussaq complex, South Greenland. Bull. Minéral., t. T111, 567-576, 3 figs, 2 tables (Misc. Pap. Grønlands geol. Unders., No. 414).

Lane, P. D. 1988: Silurian trilobites from Peary Land, central North Greenland. Rapp. Grønlands geol. Unders., Nr. 137, 93-117, 2 figs, 5 plates.

Larsen, H. C. 1988: A multiple and propagating rift model for the NE Atlantic. In Morton, A. C. \& Parson, L. M. (ed.)
Early Tertiary volcanism and the opening of the NE Atlantic. Spec. Publ. geol. Soc. Lond., No. 39, 157-158, 1 fig. (Misc. Pap. Grønlands geol. Unders., No. 410).

Larsen, H. C. \& Jakobsdóttir, S. 1988: Distribution, crustal properties and significance of seawards-dipping sub-basement reflectors off E Greenland. In Morton, A. C. \& Parson, L. M. (ed.) Early Tertiary volcanism and the opening of the NE Atlantic. Spec. Publ. geol. Soc. Lond., No. 39, 95114, (Misc. Pap. Grønlands geol. Unders., No. 409).

Larsen, L. M. \& Pedersen, A. K. 1988: Investigations of Tertiary volcanic rocks along the south coast of Nûgssuaq and in eastern Disko, 1987. Rapp. Grønlands geol. Unders., Nr. 140, 28-32, 4 figs, 1 table.

Larsen, P.-H. 1988: Relay structures in a Lower Permian basement-involved extension system, East Greenland. $J$. struct. Geol., vol. 10, 3-8, 9 figs. (Misc. Pap. Grønlands geol. Unders., No. 403).

Marcussen, C., Larsen, P.-H., Nøhr-Hansen, H., Olsen, H., Piasecki, S. \& Stemmerik, L. 1988: Studies of the onshore hydrocarbon potential in East Greenland 1986-87: field work from $73^{\circ}$ to $76^{\circ} \mathrm{N}$. Rapp. Grønlands geol. Unders., Nr. 140, 89-95, 5 figs.

Marker, M. \& Garde, A. A. 1988: Border relations between the amphibolite facies Finnefjeld gneiss complex and granulite facies grey gneisses in the Fiskefjord area, southern West Greenland. Rapp. Grønlands geol. Unders., Nr. 140, 49-54, 4 figs.

Nielsen, T. F. D. \& Escher, J. C. 1988: Reconnaissance investigations in the Skjoldungen region, South-East Greenland. Rapp. Grønlands geol. Unders., Nr. 140, 72-76, 2 figs.

Nøhr-Hansen, H. \& Koppelhus, E. B. 1988: Ordovician spores with trilete rays from Washington Land, North Greenland. Rev. Palaeobot. Palynol., vol. 56, 305-311, 2 figs, 2 plates.

Olesen, O. B. \& Clausen, A. 1988: Test drilling with hot water jet at the Inland Ice margin, Pâkitsoq, central West Greenland. Rapp. Gronlands geol. Unders., Nr. 140, 121-124, 3 figs, 2 tables.

Pedersen, G. K. \& Jeppesen, M. W. 1988: Examples of bar accretion in fluvial sand, the Atane Formation, eastern Disko, West Greenland. Rapp. Grønlands geol. Unders., Nr. 140, 38-43, 7 figs.

Peel, J. S. 1988: Molluscs of the Holm Dal Formation (late Middle Cambrian), central North Greenland. Meddr Grønland Geosci., No. 20, 145-168.

Peel, J. S. 1988: Spirellus and related helically coiled microfossils (cyanobacteria) from the Lower Cambrian of North Greenland. Rapp. Gronlands geol. Unders., Nr. 137, 5-32, 15 figs.

Peel, J. S. \& Blaker, M. R. 1988: The small shelly fossil Mongolitubulus from the Lower Cambrian of central North Greenland. Rapp. Grønlands geol. Unders., Nr. 137, 55-60, 2 figs.

Peel, J. S. \& Smith, M. P. 1988: The Wandel Valley Formation (Early - Middle Ordovician) of North Greenland and its correlatives. Rapp. Grønlands geol. Unders., Nr. 137, 61-92, 19 figs.

Peel, J. S. \& Vidal, G. 1988: Acritarchs from the Kap Holbæk Formation, North Greenland. Rapp. Gronlands geol. Un- 
ders., Nr. 137, 42 only.

Pickerill, R. K. \& Harland, T. L. 1988: Trace fossils from Silurian slope deposits, North Greenland. Rapp. Grønlands geol. Unders., Nr. 137, 119-133.

Schiøtte, L. 1988: Field occurrence and petrology of deformed metabasite bodies in the Rinkian mobile belt, Umanak district, West Greenland. Rapp. Grønlands geol. Unders., Nr. 141, 36 pp., 34 figs, 9 tables.

Schiøtte, L., Compston, W. \& Bridgwater, D. 1988: Late Archaean ages for the deposition of clastic sediments belonging to the Malene supracrustals, southern West Greenland: evidence from an ion probe U-Pb zircon study. Earth planet. Sci. Lett., vol. 87, 45-58, 5 figs, 3 tables (Misc. Pap. Grønlands geol. Unders., No. 402).

Schønwandt, H. Kr. 1988: Geology and geotectonic setting of cratonic porphyry molybdenum deposits in the North Atlantic region. In Boissonnas, J. \& Omenetto, P. (ed.) Mineral deposits within the European Community, 210-229, 6 figs, 2 tables. Berlin, Heidelberg: Springer-Verlag.

Smelror, M. 1988: Late Bathonian to Early Oxfordian dinoflagellate cyst stratigraphy of Jameson Land and Milne Land, East Greenland. Rapp. Grønlands geol. Unders., Nr. 137, 135-159, 12 figs.

Steenfelt, A. 1988: Progress in geochemical mapping of West Greenland. Rapp. Grønlands geol. Unders., Nr. 140, 17-24, 3 figs, 3 tables.

Steenfelt, A. 1988: Uranium exploration in the Precambrian of West Greenland using integrated gamma spectrometry and drainage geochemistry (summary). In IAEA (ed.) Geological data integration techniques, 165-170. Wien: International Atomic Energy Agency.

Steenfelt, A. \& Armour-Brown, A. 1988: Characteristics of the South Greenland uranium province. In IAEA (ed.) Recognition of uranium provinces, 305-335. Wien: International Atomic Energy Agency.

Stemmerik, L. 1988: A preliminary study of the porosity and permeability of limestones and sandstones in the Jameson Land area, central East Greenland. Rapp. Grønlands geol. Unders., Nr. 140, 80-84, 4 figs.

Stemmerik, L., Rouse, J. E. \& Spiro, B. 1988: S-isotope studies of shallow water, laminated gypsum and associated evaporites, Upper Permian, East Greenland. Sediment. Geol., vol. 58, 37-46, 5 figs, 1 table.

Thomassen, B., Tukiainen, T. \& Secher, K. 1988: Detailed investigation of the niobium-tantalum distribution within the Motzfeldt Centre, South Greenland. Rapp. Grønlands geol. Unders., Nr. 140, 66-70, 2 figs, 1 table.

Thomsen, H. H. 1988: Mass balance, ice velocity and ice temperature at the Inland Ice margin north-east of Jakobshavn, central West Greenland. Rapp. Grønlands geol. Unders., Nr. 140, 111-114, 2 figs, 2 tables.

Thomsen, H. H. 1988: Mapping and modelling of glacier drainage in the Pâkitsoq basin, central West Greenland. Rapp. Grønlands geol. Unders., Nr. 140, 114-117, 3 figs.

Thomsen, H. H. 1988: Glaciological research for hydropower planning in Ilulissat/Jakobshavn, West Greenland. In Thomsen, H. H., Søgaard, H. \& Braithwaite, R. J. (ed.) Applied hydrology in the development of northern basins. Proc. 7th Northern Research Basins Symposium/Workshop, 1988, Ilulissat, 47-56. København: Selskabet for Arktisk Teknologi.

Thorning, L. 1988: Introduction of new computing facilities at the Geological Survey of Greenland. Rapp. Grønlands geol. Unders., Nr. 140, 7-9, 1 fig.

Thorning, L. 1988: Reconnaissance aeromagnetic survey east of Disko Bugt, central West Greenland. Rapp. Grønlands geol. Unders., Nr. 140, 26-27, 1 fig.

Thorning, L. \& Hansen, E. 1988: Electromagnetic reflection survey 1987 in key areas of the Pâkitsoq basin at the margin of the Inland Ice, central West Greenland. Rapp. Gronlands geol. Unders., Nr. 140, 117-118.

Thorning, L. \& Hansen, E. 1988: Construction and testing of a lightweight radar for ice-thickness determinations on glaciers in the Pâkitsoq area, central West Greenland. Rapp. Grønlands geol. Unders., Nr. 140, 118-121, 5 figs.

Thorning, L., Bower, M., Hardwick, C. D. \& Hood, P. 1988: Greenland ice cap aeromagnetic survey 1987: completion of the survey over the southern end of the Greenland ice cap. Rapp. Grønlands geol. Unders., Nr. 140, 70-72, 2 figs.

Tukiainen, T. 1988: Niobium-tantalum mineralisation in the Motzfeldt Centre of the Igaliko Nepheline Syenite Complex, South Greenland. In Boissonnas, J. \& Omenetto, P. (ed.) Mineral deposits within the European Community, 230-246, 6 figs, 2 tables. Berlin, Heidelberg: Springer-Verlag (Misc. Pap. Grønlands geol. Unders., No. 411).

Vidal, G. \& Peel, J. S. 1988: Acritarchs from the Buen Formation (Lower Cambrian), North Greenland. Rapp. Grønlands geol. Unders., Nr. 137, 54 only.

Weidick, A. 1988: Surging glaciers in Greenland - a status. Rapp. Grønlands geol. Unders., Nr. 140, 106-110, 4 figs. 